\title{
Lack of association between cathepsin D C224T polymorphism and Alzheimer's disease risk: an update meta-analysis
}

\author{
Cuiju Mo ${ }^{\dagger}$, Qiliu Peng ${ }^{\dagger}$, Jingzhe Sui ${ }^{\dagger}$, Jian Wang, Yan Deng, Li Xie, Taijie Li, Yu He, Xue Qin ${ }^{*}$ and Shan Li ${ }^{*}$
}

\begin{abstract}
Background: Cathepsin D C224T polymorphism has been reported to associate with AD susceptibility. But the results were inconsistent. This study aimed to assess the relationship between C224T polymorphism and AD risk.

Methods: The relevant studies were identified by searching PubMed, Embase, Web of Science, Google Scholar and Wan fang electronic databases updated on July 2013. The relationship between Cathepsin D C224T polymorphism and $\mathrm{AD}$ risk was evaluated by ORs and $95 \% \mathrm{Cls}$.

Results: A total of 25 case-control studies including 5,602 cases and 11,049 controls were included in the metaanalysis. There was no association between C224T polymorphism and AD risk with all the studies were pooled in the meta-analysis (CT vs. CC: $\mathrm{OR}=1.125,95 \% \mathrm{Cl}=0.974-1.299, \mathrm{P}=0.109 ; \mathrm{CT}+\Pi \mathrm{T}$ vs. $\mathrm{CC}: \mathrm{OR}=1.136,95 \% \mathrm{Cl}=0.978-1.320$, $P=0.094)$. Furthermore, when stratified by ethnicity, age of onset and APOE 44 status, significant association did not found in all subgroups.
\end{abstract}

Conclusion: The present meta-analysis suggested that the Cathepsin D C224T polymorphism was not associated with AD susceptibility.

Keywords: Cathepsin D, AD, Polymorphism, Meta-analysis

\section{Background}

The neurodegenerative disorder Alzheimer's disease (AD) caused the most of dementia in the elderly [1]. Previous findings indicated that the incidence increased from $1 \%$ in 65-69 year-olds to about 50\% in 85-95 year-olds [2]. Many genetic and environmental risk factors contribute to the degenerative progress of $\mathrm{AD}$, such as family history, low income and education, exposure to aluminium in drinking water, dietary habits, smoking, physical activity, hypertension, diabetes and genetic variations [3]. Molecular genetics researches have shown that $\mathrm{AD}$ was a class of complex polygenic diseases with genetic heterogeneity. Several genes have been reported to associate with $\mathrm{AD}$. Beta-amyloid precursor protein (APP) and presenilin 2 played major role in early-onset familial AD $[4,5]$. The death-associated protein kinase 1(DAPK1) [6] and ATP-

\footnotetext{
*Correspondence: qinxue919@126.com; lis8858@126.com

${ }^{\dagger}$ Equal contributors

Department of Clinical Laboratory, First Affiliated Hospital of Guangxi Medical University, Nanning, Guangxi 530021, China
}

binding cassette subfamily A member 7 (ABCA7) [7] have been mainly implicated with late-onset $\mathrm{AD}$. The $\varepsilon 4$ allele of apolipoprotein $\mathrm{E}(A P O E \varepsilon 4)$ was the only verified risk factor for sporadic $\mathrm{AD}$ [8]. However, the presence of variants for these genes and the $A P O E \varepsilon 4$ allele was neither necessary nor sufficient for AD development. About 50\% of $\mathrm{AD}$ patients did not have mutations in the genes mentioned above or carry the $A P O E \varepsilon 4$ allele, and not everyone who has the mutations of the genes will acquire AD [9], suggesting that it is necessary to identify additional genetic or non-genetic factors which modulate the $\mathrm{AD}$ susceptibility.

The main histopathologic features of AD are neurofibrillary tangles and Neuritic plaques which consist of hyperphosphorylated tau protein and amyloid peptides, respectively. Cathepsin D (CTSD), an intracellular acid protease, contributed to the proteolytic cleavage of APP and the clearance of the $\beta$-amyloid $(A \beta)$ from the central nervous system $[10,11]$. As such, CTSD might involve in the pathogenesis of AD. Variants of CTSD gene might 
impede the functions of proteolytic degradation, thus increasing the risk of AD. A CTSD C224T polymorphism (C-to- $\mathrm{T}$ ) in exon 2 can bring about amino acid change (Ala38-to-Val), increase pro-CTSD secretion and alter intracellular maturation [12]. It has been proved that this polymorphism was significantly associated with the general intelligence of healthy elderly [13].

Recently, numerous studies have focused on the correlation between the CTSD C224T polymorphism and AD risk [14-36]. Unfortunately, the results of these studies were contradictory. Five previous studies reported that the $T$ allele of the $C T S D-C / T$ polymorphism was a high-risk factor for developing AD [14-18]; however, other relevant studies yielded contradictory results [19-36]. Furthermore, the results of previous meta-analysis which research the association between the CTSD polymorphism and AD risk were contradictory as well. Bertram et al. [37] and Ntais et al. [38] did not find any significant association, whereas Schuur [18] reported that $T$ allele increased the risk of $\mathrm{AD}$ in Caucasians. Possible reasons for these contradictory results include the small sample size of the Ntais study; the absence of an Asian population in the Schuur study; and the fact that the Bertram study only compared alleles $T$ and $C$. Considering that those factors could contribute to bias in the final result, we updated the present meta-analysis which included a larger sample size to provide a more reliable correlation between CTSD C224T and AD.

\section{Methods}

\section{Search strategy}

The relevant studies were identified by searching PubMed, Embase, Web of Science, Google Scholar and Wan fang electronic databases in July 2013 for all the articles regarding the correlation between CTSD C224T polymorphism and $\mathrm{AD}$ risk. The key words of search strategy as follow: "Alzheimer's disease or AD”, "CTSD or cathepsin D”, and "polymorphism, mutation or variant". References listed in reviews and retrieved articles were also screened. There were no language or country restrictions. When multiple articles researched the same cohort, the one with the largest population was included. When a publication reported more than one subpopulation, we regarded every subpopulation as a separate study.

\section{Selection criteria}

The eligible studies were requested to agree with the inclusion criteria: (1) a case-control study; (2) research of the correlation between CTSD C224T polymorphism and AD susceptibility; (3)inclusion of the sample size and distribution of alleles and genotypes; (4) AD diagnosed according to the criteria of the National Institute of Neurological and Communicative Disorders and Stroke and the Alzheimer's Disease and Related Disorders Association
(NINCDS-ADRDA), or the Diagnostic and Statistical Manual of Mental Disorders, Fourth Edition (DSM-IV). Exclusion criteria of our study were followed as: (1) duplicated literature, reviews, or animal studies; (2) genotype frequency and distribution were not included; (3) not enough information for data extraction.

\section{Data extraction}

Two reviewers (Cuiju Mo and Jingzhe Sui) extracted the information independently. If there was a disagreement, the data was checked again, and a third reviewer (Xue Qin) was invited to check the data. Information collected from each eligible study was included: first author, year of publication, country, ethnicity, genotyping method, AD diagnosis, control sources, sample sizes, age of onset, and genotype distribution in cases and controls.

\section{Statistical analysis}

All analysis was conducted using Stata version 12.0 software (Stata Corp, College Station, TX). The association was assessed by pooled odds ratio (OR) together with the corresponding 95\% confidence interval (CI). Only heterozygote comparison model (TC vs. $\mathrm{CC}$ ) and the dominant genetic model (TT + TC vs. $\mathrm{CC}$ ) were analysed. Furthermore, we evaluated the effect in different subgroup stratified by ethnicity (Asian vs. Caucasian) and age of onset. Early-onset AD (EOAD) was defined as age at onset $<65$ years, and age at onset $\geq 65$ years was considered as late-onset AD (LOAD). To evaluate the interaction of the CTSD with the APOEE4 allele, we compared the dominant genetic model (TT $+\mathrm{TC}$ vs. $\mathrm{CC}$ ) between case and control subjects stratified by the APOE\&4 allele status. Similarly, the relationship of the $A P O E \varepsilon 4$ allele with $\mathrm{AD}$ risk was investigated between the patients carrying the $T$ allele or not.

The $\mathrm{x}^{2}$-test based Q-statistic and $\mathrm{I}^{2}$ statistic was used to evaluate the heterogeneity among the studies. The DerSimonian-Laird random-effects model was used to assess pooled $\mathrm{OR}$ when a significant heterogeneity $\left(\mathrm{P}_{\mathrm{Q}}<\right.$ 0.1 or $\mathrm{I}^{2} \geq 50 \%$ ) was observed. Otherwise, the MantelHaenszel fixed-effects model was used. The publication bias was detected by funnel plot and Egger's test. An Egger's test $\mathrm{P}$ value $<0.05$ was considered as statistically significant. The genotype distribution of the control population was used to evaluate Hardy-Weinberg Equilibrium (HWE) by a goodness-of-fit Chi-square test. $\mathrm{P}<0.05$ (twoside) was considered as statistically significant.

\section{Results}

\section{Eligible studies}

Figure 1 showed the screening process of our study. A total of 345 articles were identified from the database searching and references of review. 31 relevant articles were identified according to inclusion criteria. Then eight 


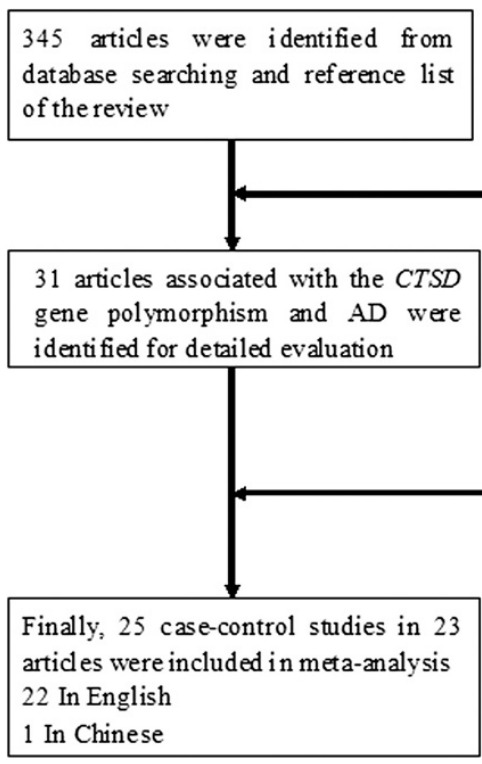

Figure 1 Flow chart of literature screening for this meta-analysis.
314 articles were excluded after reading the title and abstract

Publications excluded after reading the full article in detail 1 article was meta-analysis 2 articles did not provide the sufficient data

5 articles were excluded as overlapped articles were excluded based on the full texts: one article was a meta-analysis [38], two articles did not provide sufficient data $[39,40]$, and five articles overlapped with other published studies [32,41-44]. Finally, 23 articles including 22 English papers and 1 Chinese paper [19] were included in our study. Two out of the including articles reported two subpopulations, and each subpopulation was considered as a separate study. Therefore, 25 case-control studies including 5,602 cases and 11,049 controls were included in the meta-analysis, encompassing 4 Asian and 21 Caucasian samples. All AD patients were diagnosed by NINCDS-ADRDA criteria, DSM-IV criteria, or autopsy confirmation in all eligible studies. The genotype frequencies of the control groups in two case-control studies deviated from the HWE [22,29]. Ten of the eligible studies evaluated the interaction between the CTSD and the APOEE4 allele [1,14,15,18-21,24,28,29,34]. Six of the studies included early-onset and late-onset cases $[20,21,28,29,33,34]$. The baseline data of each case-control study were presented in Table 1.

\section{Results of meta-analysis}

The present finding of this meta-analysis revealed that the $C 224 T$ polymorphism was not associated with AD risk. The heterogeneities of $\mathrm{CT}$ vs. $\mathrm{CC}$ and the dominant $\mathrm{CT}+\mathrm{TT}$ vs. CC models were assessed in the overall population, and the $\mathrm{P}_{\mathrm{Q}}$ values were 0.023 and 0.007 , respectively. Thus, random-effects model was chose to analyse the CT vs. CC model $(\mathrm{OR}=1.125,95 \% \mathrm{CI}=$ 0.974-1.299, $\mathrm{P}=0.109$, Table 2, Figure $2 \mathrm{~A}$ ) and the dominant CT + TT vs. CC model $(\mathrm{OR}=1.136,95 \% \mathrm{CI}=$ $0.978-1.320, \mathrm{P}=0.094$, Table 2, Figure $2 \mathrm{~B}$ ) in the overall population. The control genotypes of two case-control studies [22,29] deviated from the HWE. The summary ORs were slightly elevated in the CT vs. CC (OR = 1.127, 95\% CI $=0.965-1.317, \mathrm{P}=0.132)$ and dominant $\mathrm{CT}+\mathrm{TT}$ vs. CC models $(\mathrm{OR}=1.149,95 \% \mathrm{CI}=0.978-1.35$, $\mathrm{P}=0.09$ ) without a statistical significance, when we excluded those two studies.

In subgroup analyses stratified by ethnicity, we failed to find any significant associations between the CTSD C224T polymorphism and AD risk in the Asian (CT vs. $\mathrm{CC}: \mathrm{OR}=0.971,95 \% \mathrm{CI}=0.626-1.506, \mathrm{P}=0.895 ; \mathrm{CT}+$ TT vs. $\mathrm{CC}: \mathrm{OR}=0.954,95 \% \mathrm{CI}=0.616-1.477, \mathrm{P}=0.833$, Table 2) and Caucasian(CT vs. CC: $\mathrm{OR}=1.139,95 \% \mathrm{CI}=$ 0.974-1.331, $\mathrm{P}=0.102 ; \mathrm{CT}+\mathrm{TT}$ vs. $\mathrm{CC}: \mathrm{OR}=1.154,95 \%$ $\mathrm{CI}=0.982-1.357, \mathrm{P}=0.082$, Table 2 ) populations. After excluding two studies $[22,29]$ which deviated from the HWE, no significant associations were found between the CTSD C224T polymorphism and AD risk in the Asian (CT + TT vs. $\mathrm{CC}$ : $\mathrm{OR}=0.968,95 \% \mathrm{CI}=0.605-1.548, \mathrm{P}=0.891)$ and Caucasian (CT + TT vs. CC: $\mathrm{OR}=1.165,95 \%$ CI $=0.981-$ $1.383, \mathrm{P}=0.081$ ). Similarly, we found non-significant associations in the EOAD (CT vs. $\mathrm{CC}: \mathrm{OR}=0.937,95 \% \mathrm{CI}=$ 0.706-1.245, $\mathrm{P}=0.654 ; \mathrm{CT}+\mathrm{TT}$ vs. $\mathrm{CC}: \mathrm{OR}=0.930,95 \%$ $\mathrm{CI}=0.704-1.229, \mathrm{P}=0.612)$ and LOAD (CT vs. CC: $\mathrm{OR}=$ 0.935, 95\% CI $=0.724-1.207, \mathrm{P}=0.606 ; \mathrm{CT}+\mathrm{TT}$ vs. $\mathrm{CC}$ : $\mathrm{OR}=0.931,95 \% \mathrm{CI}=0.726-1.195, \mathrm{P}=0.575)$ subgroups in any of the comparisons (Table 2).

In the $A P O E \varepsilon 4$ stratified analyses, the results did not show significant associations between the C224T polymorphism and AD risk in APOE\&4 carriers and noncarriers. However, the pooled OR were higher in APOE\&4 carriers $(\mathrm{CT}+\mathrm{TT}$ vs. $\mathrm{CC}$ : $\mathrm{OR}=1.267,95 \% \mathrm{CI}=0.979-1.641$, 
Table 1 The baseline data of all including study

\begin{tabular}{|c|c|c|c|c|c|c|c|c|c|}
\hline First author & Year & Country & Ethnicity & $\begin{array}{l}\text { Genotyping } \\
\text { method }\end{array}$ & AD diagnostic & $\begin{array}{l}\text { Control } \\
\text { sources }\end{array}$ & HWE & $\begin{array}{l}\text { Case } \\
\text { (EOAD/LOAD) }\end{array}$ & Control \\
\hline Sun & 2005 & China & Asian & PCR-RFLP & $\begin{array}{l}\text { NINCDS-ADRDA and } \\
\text { DSM-IV }\end{array}$ & PB & 0.552 & 165 & 174 \\
\hline Li & 2004 & China & Asian & PCR-RFLP & NINCDS-ADRDA & PB & 0.484 & $156(42 / 114)$ & 183 \\
\hline Jhoo & 2005 & Korea & Asian & DASH & NINCDS-ADRDA & PB & 0.701 & 107(36/71) & 216 \\
\hline \multirow[t]{2}{*}{ Matsui } & 2001 & Japan & Asian & PCR-RFLP & NINCDS-ADRDA & PB & 0.000 & 275 & 479 \\
\hline & & USA & Caucasian & PCR-RFLP & autopsy-confirmed & PB & 0.191 & 69 & 50 \\
\hline Papassotiropoulos & 1999 & Germany & Caucasian & PCR-RFLP & NINCDS-ADRDA & PB & 0.21 & 102 & 351 \\
\hline Mcllroy & 1999 & Ireland & Caucasian & PCR-RFLP & $\begin{array}{l}\text { DSM IV and } \\
\text { NINCDS-ADRDA }\end{array}$ & PB & 0.367 & 183 & 187 \\
\hline Papassotiropoulos & $2000(b)$ & Germany & Caucasian & PCR-RFLP & NINCDS-ADRDA & $\mathrm{HB}$ & 0.485 & 127 & 184 \\
\hline Bhojak & 2000 & USA & Caucasian & PCR-RFLP & NINCDS-ADRDA & $\mathrm{HB}$ & 0.084 & 531 & 316 \\
\hline \multirow[t]{2}{*}{ Crawford } & 2000 & USA & Caucasian & PCR-RFLP & NINCDS-ADRDA & $\mathrm{HB}$ & 0.319 & 210 & 120 \\
\hline & & Spain & Caucasian & PCR-RFLP & NINCDS-ADRDA & $\mathrm{HB}$ & 0.101 & 79 & 112 \\
\hline Menzer & 2001 & $\begin{array}{l}\text { Germany, } \\
\text { Switzerland, Italy }\end{array}$ & Caucasian & PCR-RFLP & NINCDS-ADRDA & $\mathrm{HB}$ and $\mathrm{PB}$ & 0.988 & 324 & 302 \\
\hline Bertram & 2001 & USA & Caucasian & PCR-RFLP & NINCDS-ADRDA & $\mathrm{HB}$ & 0.373 & 200 & 182 \\
\hline Emahazion & 2001 & Scotland & Caucasian & DASH & DSM-IV & Not clarified. & 0.329 & 120 & 149 \\
\hline Bagnoli & 2002 & Italy & Caucasian & PCR-RFLP & DSM-IV & PB & 0.616 & 197(33/33) & 126 \\
\hline Mateo & 2002 & Spain & Caucasian & PCR-RFLP & NINCDS-ADRDA & $\mathrm{HB}$ & 0.008 & $311(126 / 185)$ & 346 \\
\hline Styczynska & 2003 & Polish & Caucasian & PCR-RFLP & NINCDS-ADRDA & $\mathrm{HB}$ & 0.637 & 100 & 100 \\
\hline Ingegni & 2003 & Italy & Caucasian & PCR-RFLP & NINCDS-ADRDA & $\mathrm{HB}$ & 0.914 & 142 & 120 \\
\hline Beryer & 2005 & Spain & Caucasian & PCR-RFLP & $\begin{array}{l}\text { DSM-IV and } \\
\text { NINCDS-ADRDA }\end{array}$ & Not clarified. & 0.871 & 205 & 181 \\
\hline Blomqvist2 & 2006 & Switzerland & Caucasian & DASH & NINCDS-ADRDA & $\mathrm{HB}$ and $\mathrm{PB}$ & 0.372 & 385 & 173 \\
\hline Mariani & 2006 & Italy & Caucasian & PCR-RFLP & NINCDS-ADRDA & PB & 0.355 & 100 & 136 \\
\hline Davidson & 2006 & UK & Caucasian & PCR-RFLP & NINCDS-ADRDA & $\mathrm{HB}$ & 0.168 & $560(317 / 243)$ & 767 \\
\hline Capurso & 2008 & Italy & Caucasian & PCR-RFLP & NINCDS-ADRDA & PB & 0.205 & 242(57/185) & 421 \\
\hline Albayrak & 2010 & Germany & Caucasian & PCR-RFLP & NINCDS-ADRDA & $\mathrm{HB}$ & 0.143 & 219 & 215 \\
\hline M. Schuur & 2011 & Netherland & Caucasian & Taqman assay & NINCDS-ADRDA & PB & 0.631 & 493 & 5619 \\
\hline
\end{tabular}

$P C R-R F L P$, Polymerase chain reaction-restriction fragment length polymorphism; $D A S H$, dynamic allele specific hybridization; $P B$, Population-based; $H B$, Hospital-based; $H W E$, hardy-Weinberg equilibrium; $E O A D$, early-onset $A D ; L O A D$, late-onset $A D$.

$\mathrm{P}=0.072$, Table 3$)$ than in non-carriers $(\mathrm{CT}+\mathrm{TT}$ vs. $\mathrm{CC}$ : $\mathrm{OR}=1.139,95 \% \mathrm{CI}=0.844-1.539, \mathrm{P}=0.395$, Table 3). Furthermore, among the $T$ allele carriers, $A P O E \varepsilon 4$ allele increased the risk of $\mathrm{AD} 4.5$-fold $(\mathrm{OR}=4.532,95 \% \mathrm{CI}=$ 2.755-7.455, $\mathrm{P}=0.000$, Table 3 ) accompanied by heterogeneity $(\mathrm{P}=0.033)$. Among the subjects without the $T$ allele, $A P O E \varepsilon 4$ increased the risk of $\mathrm{AD} 4.2$-fold $(\mathrm{OR}=$ 4.193, 95\% CI $=3.096-5.679, \mathrm{P}=0.000$, Table 3 ) with significant between-study heterogeneity $(\mathrm{P}=0.000)$. Extensive overlap existed between the two estimates; however, the ORs were greater in the $T$ allele carriers.

\section{Publication bias}

There was no visible publication bias among the studies because of the shape of the Begg's funnel plots revealed symmetry in the $\mathrm{CT}$ vs. $\mathrm{CC}$ and $\mathrm{CT}+\mathrm{TT}$ vs. $\mathrm{CC}$ comparative genetic models (Figure 3). Statistical evidence of funnel plot symmetry was provided by Egger's test. The results also showed no publication bias in the C224T polymorphism $(\mathrm{t}=-0.19, \mathrm{P}=0.853$ for $\mathrm{CT}$ vs. $\mathrm{CC} ; \mathrm{t}=-0.34$, $\mathrm{P}=0.736$ for $\mathrm{CT}+\mathrm{TT}$ vs. CC).

\section{Discussion}

The effects of genetic sequence variants in complex human traits are not readily detectable in population samples. However, meta-analysis that accumulates published data from small single research is a valuable tool in identifying disease genes. The functions of CTSD are to hydrolyse APP protein and clear A $\beta$ from the central nervous system $[10,11]$. In AD patients, CTSD was expressed in the core of neuritic plaques [45], and cellular and cerebrospinal levels are elevated [46]. The variants 
Table 2 Results of the association between CTSD C224T polymorphism and AD risk in the meta-analysis

\begin{tabular}{|c|c|c|c|c|c|c|c|c|c|}
\hline \multirow[t]{2}{*}{ Comparison } & \multirow[t]{2}{*}{ Population } & \multirow[t]{2}{*}{ No. of studies } & \multicolumn{3}{|c|}{ Test of association } & \multirow[t]{2}{*}{ Mode } & \multicolumn{3}{|c|}{ Test of heterogeneity } \\
\hline & & & OR & $95 \% \mathrm{Cl}$ & P Value & & $x^{2}$ & $\mathrm{P}_{\mathrm{Q}}$ Value & $\mathrm{I}^{2}$ \\
\hline CT vs. CC & Overall & 25 & 1.125 & $0.974-1.299$ & 0.109 & $\mathrm{R}$ & 39.65 & 0.023 & 39.5 \\
\hline$C T+\pi$ vs. CC & Overall & 25 & 1.136 & $0.978-1.320$ & 0.094 & $\mathrm{R}$ & 44.23 & 0.007 & 45.7 \\
\hline \multicolumn{10}{|l|}{ Subgroup analysis } \\
\hline \multicolumn{10}{|l|}{ Ethnicity } \\
\hline \multirow[t]{2}{*}{ CT vs. CC } & Asian & 4 & 0.971 & $0.626-1.506$ & 0.895 & $\mathrm{~F}$ & 2.04 & 0.565 & 0.0 \\
\hline & Caucasian & 21 & 1.139 & $0.974-1.331$ & 0.102 & $\mathrm{R}$ & 37.20 & 0.011 & 46.2 \\
\hline \multirow[t]{2}{*}{$C T+\Pi$ vs. $C C$} & Asian & 4 & 0.954 & $0.616-1.477$ & 0.833 & $\mathrm{~F}$ & 2.04 & 0.565 & 0.0 \\
\hline & Caucasian & 21 & 1.154 & $0.982-1.357$ & 0.082 & R & 41.54 & 0.003 & 51.8 \\
\hline \multicolumn{10}{|l|}{ EOAD } \\
\hline CT vs. CC & Overall & 6 & 0.937 & $0.706-1.245$ & 0.654 & $\mathrm{~F}$ & 2.87 & 0.719 & 0.0 \\
\hline$C T+\pi$ vs. CC & Overall & 6 & 0.93 & $0.704-1.229$ & 0.612 & $\mathrm{~F}$ & 2.68 & 0.749 & 0.0 \\
\hline \multicolumn{10}{|l|}{ LOAD } \\
\hline CT vs. CC & Overall & 6 & 0.935 & $0.724-1.207$ & 0.606 & $\mathrm{~F}$ & 3.86 & 0.57 & 0.0 \\
\hline $\mathrm{CT}+\mathrm{TT}$ vs. $\mathrm{CC}$ & Overall & 6 & 0.931 & $0.726-1.195$ & 0.575 & $\mathrm{~F}$ & 3.88 & 0.567 & 0.0 \\
\hline
\end{tabular}

$O R$, odds ratio; $C l$, confidence intervals; $R$, random effects model; $F$, fixed effects model; $E O A D$, early-onset $A D ; L O A D$, late-onset $A D$.

of this gene might impede the proteolytic cleavage of APP and the degradation and clearance of A $\beta$, the synthesis of which is a supposed pivotal event in the pathogenesis of AD. Therefore, our motivation for the present study was to determine the association between CTSD polymorphism and $\mathrm{AD}$ risk from abundant data over 16,651 genotype cases and controls.

As far as we know, the present meta-analysis involving 5602 cases and 11,049 healthy controls was the most comprehensive to date to investigate the relation between the CTSD C224T polymorphism and AD susceptibility. Our finding indicated that the $C 224 T$ polymorphism was not associated with the AD risk both in Asian and Caucasian populations, which were in accord with the results of the previous meta-analysis [38] and inconsistent with Schuur's results [18]. Compared to the previous study, our metaanalysis has some particular strength. First, we had the largest sample size; we added four Asian population studies, the absence of which in the Schuur study might have caused a deviation in the final result; and ten new casecontrol studies were added compared to the Ntais study, which might have effectively altered the overall results. Second, because nearly half of the eligible studies did not detect the homozygous TT polymorphism, and the

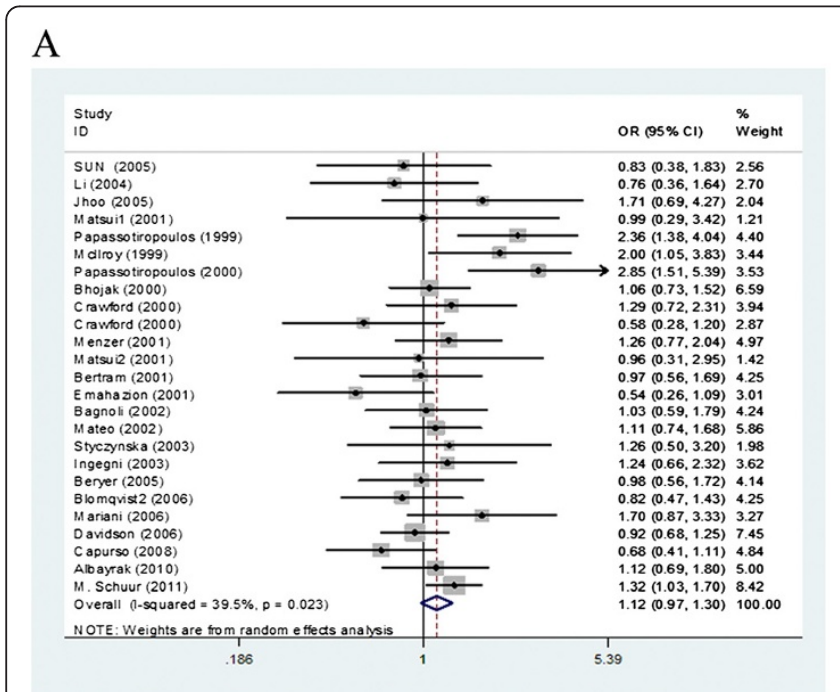

B

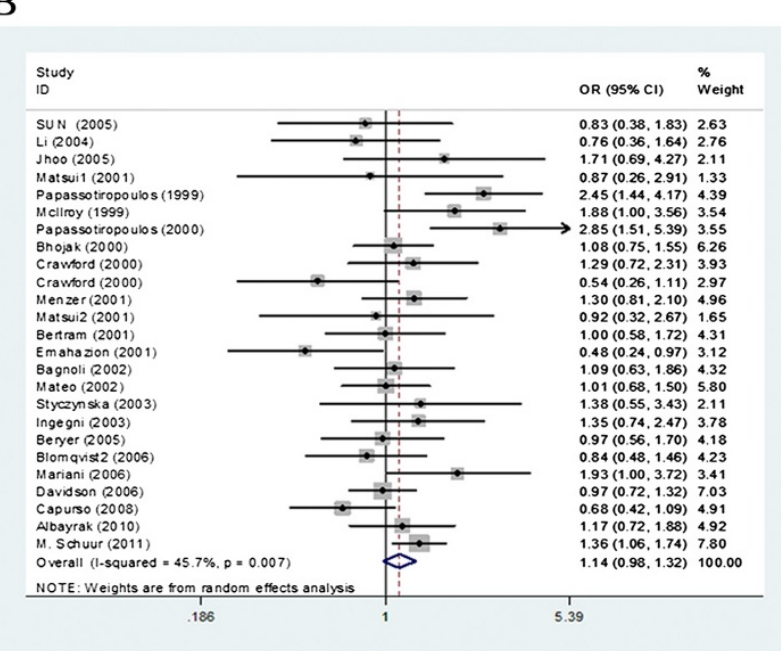

Figure 2 Forest plots of CTSD C224T polymorphism and AD risk ( $\mathrm{A}, \mathrm{CT}$ vs. CC model; $\mathrm{B}, \mathrm{TT}+\mathrm{CT}$ vs. CC model) in all analysis using random-effect model. 
Table 3 Meta-analysis the association of CTSD C224T polymorphism with APOE\&4 carrier in AD

\begin{tabular}{|c|c|c|c|c|c|c|c|c|c|}
\hline \multirow[t]{2}{*}{ Comparison } & \multirow[t]{2}{*}{ Population } & \multirow[t]{2}{*}{ No. of studies } & \multicolumn{3}{|c|}{ Test of association } & \multirow[t]{2}{*}{ Mode } & \multicolumn{3}{|c|}{ Test of heterogeneity } \\
\hline & & & OR & $95 \% \mathrm{Cl}$ & $P$ Value & & $x^{2}$ & PQ Value & $1^{2}$ \\
\hline \multicolumn{10}{|l|}{ APOE $\varepsilon 4$ noncarriers } \\
\hline \multirow[t]{3}{*}{$C T+\pi$ vs. $C C$} & Overall & 10 & 1.139 & $0.844-1.539$ & 0.395 & $\mathrm{R}$ & 19.28 & 0.023 & 53.3 \\
\hline & Asian & 3 & 0.73 & $0.390-1.365$ & 0.324 & $\mathrm{~F}$ & 5.81 & 0.055 & 65.5 \\
\hline & Caucasian & 7 & 1.212 & $0.998-1.472$ & 0.052 & $\mathrm{~F}$ & 11.86 & 0.065 & 49.4 \\
\hline \multicolumn{10}{|l|}{ APOE\&4 carriers } \\
\hline \multirow[t]{2}{*}{$C T+\Pi$ vs. $C C$} & Overall & 10 & 1.267 & $0.979-1.641$ & 0.072 & $\mathrm{~F}$ & 10.89 & 0.283 & 17.4 \\
\hline & Asian & 3 & 1.273 & $0.511-3.184$ & 0.604 & $\mathrm{~F}$ & 0.01 & 0.995 & 0.0 \\
\hline $\mathrm{T}$ carriers & Caucasian & 7 & 1.267 & $0.979-1.641$ & 0.085 & $\mathrm{~F}$ & 10.88 & 0.092 & 44.9 \\
\hline \multirow[t]{3}{*}{ APOE $\varepsilon 4(+)$ vs. APOE $\varepsilon 4(-)$} & Overall & 10 & 4.532 & $2.755-7.455$ & 0.000 & $\mathrm{R}$ & 18.16 & 0.033 & 50.4 \\
\hline & Asian & 3 & 7.913 & $2.632-23.785$ & 0.000 & $\mathrm{~F}$ & 0.20 & 0.904 & 0.0 \\
\hline & Caucasian & 7 & 4.134 & $2.338-7.310$ & 0.000 & $\mathrm{R}$ & 15.58 & 0.016 & 61.5 \\
\hline \multicolumn{10}{|l|}{ T noncarriers } \\
\hline \multirow[t]{3}{*}{ APOE $\varepsilon 4(+)$ vs. APOE $\varepsilon 4(-)$} & Overall & 10 & 4.193 & $3.096-5.679$ & 0.000 & $\mathrm{R}$ & 43.54 & 0.000 & 79.3 \\
\hline & Asian & 3 & 4.217 & $2.333-7.620$ & 0.000 & $\mathrm{R}$ & 6.88 & 0.032 & 70.9 \\
\hline & Caucasian & 7 & 4.195 & $2.888-6.093$ & 0.000 & $\mathrm{R}$ & 35.89 & 0.000 & 83.3 \\
\hline
\end{tabular}

$O R$, odds ratio; $C l$, confidence intervals; $R$, random effects model; $F$, fixed effects model.

proportion of $T T$ was very small, as is usual in common polymorphisms, heterozygote might be responsible for the significant difference in frequency; therefore, we only compared the CT vs. CC and the dominant CT + TT vs. CC models. Lastly, no significant publication bias was observed in any of the studies analyzing by Egger's test and Begg's funnel plot. Thus, based on the above factors, the results of our meta-analysis were more reliable than those of previous studies.

Our results from the $\mathrm{CT}$ vs. $\mathrm{CC}$ and dominant $\mathrm{CT}+$ TT vs. CC comparison models suggested that no significant correlation was existed between the CTSD C224T polymorphism and AD risk. Given that the control genotypes of two case-control studies [22,29] were out of
HWE, they might have contributed some bias to our summary OR. When we excluded those two studies, the summary OR was not effectively altered, showing that our result was reliable. A great degree of heterogeneity among studies was identified for CT vs. CC $\left(x^{2}=39.65\right.$, $\left.\mathrm{P}_{\mathrm{Q}}=0.023\right)$ and $\mathrm{CT}+\mathrm{TT}$ vs. $\mathrm{CC}\left(\mathrm{x}^{2}=44.23, \mathrm{P}_{\mathrm{Q}}=0.007\right)$ in the overall populations. Several factors might contribute to the heterogeneity. First, AD is a complicated and multi-genetic disease. Second, clinical heterogeneity, such as gender, age of onset, and diagnosis criteria, were factors. The different studied populations, such as ethnicity, might also explain the discrepancy. In subgroup analysis stratified by ethnicity and age of onset, heterogeneity only existed in the Caucasian subgroup, indicating
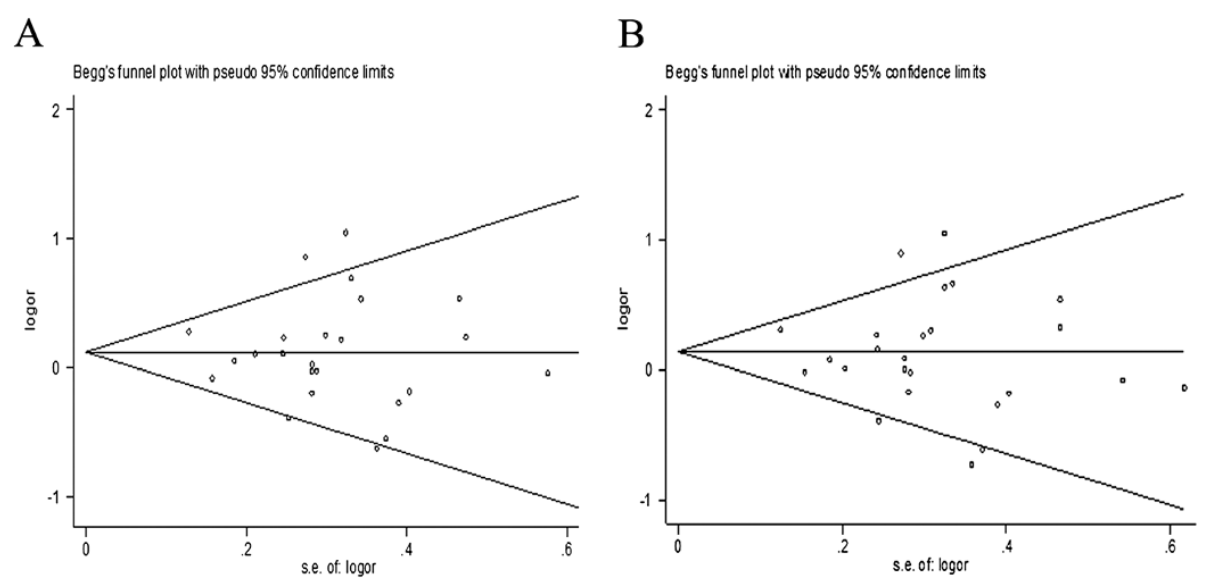

Figure 3 Funnel plot for publication bias of all eligible studies (A, CT vs. CC; B, CT + TT vs. CC). 
that age was the major contributor to the existence of all heterogeneity.

Considering the impact on the summary OR of different ethnicities, we further performed subgroup analysis based on ethnicity. Those results indicated no significant association between the CTSD C224T polymorphism and $\mathrm{AD}$ risk either in Asian or in Caucasian population, which was inconsistent with the previous meta-analysis [18]. Similarly, the results did not change when the two studies that violated HWE [22,29] were excluded. The number of samples in the Asian subgroup was dramatically less than those in the Caucasian subgroup, which may weaken the conclusions. Our results also differed from the Schurr study after excluding the Mateo study in Caucasian population. While after excluding Albayrak [39] and Mateo [33] study, a significant association was found in the dominant CT $+\mathrm{TT}$ vs. CC genetic model $(\mathrm{OR}=1.201,95 \% \mathrm{CI}=1.004-1.436, \mathrm{P}=0.045)$. The principal cause for the difference with our results was the inclusion of the Albayrak [39] study. The Albayrak study reported that the CTSD C224T polymorphism increased $\mathrm{AD}$ risk in men only which might cause the false-negative result. As no study has clarified gender-specific differences regarding lysosomes or its components and the characteristic lesions in $\mathrm{AD}$, therefore, future study with larger samples to investigate the gender-specific is necessary. When stratified by age of onset, we found no significant differences both in EOAD and LOAD subsets. Possible explanations for these findings might be the small sample sizes for analysis; the same control source, without strict age matching, and missing age information in some studies. Given these factors may affect the statistical power. Further research is required to assess the gene effects and validate our findings.

To evaluate the interaction of CTSD polymorphism and $A P O E \varepsilon 4$ allele on $\mathrm{AD}$, ten studies which provided genotype distribution data of APOE\&4 status were chosen for further study, and of which only four showed evidence of an association [14,15,20,25]. The results of our study showed non-significant relation between the $C 224 T$ polymorphism and $\mathrm{AD}$ risk in APOE\&4 carriers and non-carriers. The association of CTSD T allele with $\mathrm{AD}$ risk between $A P O E \varepsilon 4$ carriers and non-carriers in Caucasians was quite similar, contrary to the Schuur result. Due to the lack of an Asian population in the Schuur study, sample size and ethnicity might have contributed to some bias in the final result. While the ORs of $A P O E \varepsilon 4$ were greater in the $T$ allele carriers group than the subjects without the $T$ allele. Because of the extensive overlap in two effect sizes and the remarkably small group of subjects who carry both the APOE\&4 and CTSD $T$ alleles, the association between the CTSD $T$ and APOE\&4 alleles should be interpreted cautiously.
There were some limitations that merit attention. First, some of the eligible studies lacked sufficient information for detailed and deep analysis. In some studies, the controls were not uniformly defined as matched by age and gender; and it may lead to some negative correlation. Second, we mainly focused on the C224T polymorphism, discounted the potential linkage disequilibrium with another mutation of this gene, and ignored the interactions between gene and gene or gene and environment. Third, the data of our metaanalysis was unadjusted; the suspected factors could be analysed, such as, gender, diet, lifestyle habit, and environmental factors. Fourth, we included the English or Chinese publications only; the lack of unpublished data and data published in other languages might contribute some bias. There were only four articles in the Asian subgroup, with small sample size, which may cause low statistical power.

\section{Conclusions}

The finding of our present study revealed that the CTSD $C 224 T$ polymorphism was not associated with AD risk both in the overall populations and the subgroups stratified by ethnicity and age of onset. In addition, we found no statistically significant differences between the CTSD $C 224 T$ genotypes and $\mathrm{AD}$ stratified by APOE\&4 allele status. Our data did not suggest that the CTSD C224T polymorphism was a possible susceptibility factor for AD. Future studies will require much larger sample sizes and will need to analyse the impact of this polymorphism in other populations.

\section{Abbreviations}

AD: Alzheimer's disease; CTSD: Cathepsin D; APOE: Apollipoprotein E; EOAD: Early-onset AD; LOAD: Late-onset AD.

\section{Competing interests}

All authors state no conflict of interest.

\section{Authors' contributions}

$C M, Q L, X Q$, SL originally designed the study, collected the literature data and drafted the manuscript. JS, JW, YD performed data extraction and statistical analysis. $L X, T L, Y H$ executed literature search and checked the results. All authors have read and agreed with the final manuscript.

Received: 24 August 2013 Accepted: 27 November 2013

Published: 15 January 2014

\section{References}

1. Caracciolo B, Palmer K, Monastero R, Winblad B, Backman L, Fratiglioni L: Occurrence of cognitive impairment and dementia in the community: a 9-year-long prospective study. Neurology 2008, 70(19 Pt 2):1778-1785.

2. Gao S, Hendrie HC, Hall KS, Hui S: The relationships between age, sex, and the incidence of dementia and Alzheimer disease: a meta-analysis. Arch Gen Psychiatry 1998, 55(9):809-815.

3. Launer LJ, Andersen K, Dewey ME, Letenneur L, Ott A, Amaducci LA, Brayne C, Copeland JR, Dartigues JF, Kragh-Sorensen P, et al: Rates and risk factors for dementia and Alzheimer's disease: results from EURODEM pooled analyses. EURODEM Incidence Research Group and Work Groups. European Studies of Dementia. Neurology 1999, 52(1):78-84. 
4. Campion D, Dumanchin C, Hannequin D, Dubois B, Belliard S, Puel M, Thomas-Anterion C, Michon A, Martin C, Charbonnier F, et al: Early-onset autosomal dominant Alzheimer disease: prevalence, genetic heterogeneity, and mutation spectrum. Am J Hum Genet 1999, 65(3):664-670.

5. Rocca WA, Hofman A, Brayne C, Breteler MM, Clarke M, Copeland JR, Dartigues JF, Engedal K, Hagnell O, Heeren TJ, et al: Frequency and distribution of Alzheimer's disease in Europe: a collaborative study of 1980-1990 prevalence findings. The EURODEM-Prevalence Research Group. Ann Neurol 1991, 30(3):381-390.

6. Li Y, Grupe A, Rowland C, Nowotny P, Kauwe JS, Smemo S, Hinrichs A, Tacey K, Toombs TA, Kwok S, et al: DAPK1 variants are associated with Alzheimer's disease and allele-specific expression. Hum Mol Genet 2006, 15(17):2560-2568.

7. Reitz C, Jun G, Naj A, Rajbhandary R, Vardarajan BN, Wang LS, Valladares O, Lin CF, Larson EB, Graff-Radford NR, et al: Variants in the ATP-binding cassette transporter (ABCA7), apolipoprotein E 4, and the risk of late-onset Alzheimer disease in African Americans. JAMA 2013, 309(14):1483-1492.

8. Coon KD, Myers AJ, Craig DW, Webster JA, Pearson JV, Lince DH, Zismann $V L$, Beach TG, Leung D, Bryden L, et al: A high-density whole-genome association study reveals that APOE is the major susceptibility gene for sporadic late-onset Alzheimer's disease. J Clin Psychiatry 2007, 68(4):613-618.

9. Carrasquillo MM, Belbin O, Hunter TA, Ma L, Bisceglio GD, Zou F, Crook JE, Pankratz VS, Sando SB, Aasly JO, et al: Replication of BIN1 association with Alzheimer's disease and evaluation of genetic interactions. J Alzheimers Dis 2011, 24(4):751-758.

10. Sadik G, Kaji H, Takeda K, Yamagata F, Kameoka Y, Hashimoto K, Miyanaga K, Shinoda T: In vitro processing of amyloid precursor protein by cathepsin D. Int J Biochem Cell Biol 1999, 31(11):1327-1337.

11. Wischik CM, Novak M, Thogersen HC, Edwards PC, Runswick MJ, Jakes R, Walker JE, Milstein C, Roth M, Klug A: Isolation of a fragment of tau derived from the core of the paired helical filament of Alzheimer disease. Proc Natl Acad Sci USA 1988, 85(12):4506-4510.

12. Touitou I, Capony F, Brouillet JP, Rochefort H: Missense polymorphism (C/T224) in the human cathepsin D pro-fragment determined by polymerase chain reaction-single strand conformational polymorphism analysis and possible consequences in cancer cells. Eur J Cancer 1994, 30A(3):390-394.

13. Payton A, Holland F, Diggle P, Rabbitt P, Horan M, Davidson Y, Gibbons L, Worthington J, Ollier WE, Pendleton N: Cathepsin D exon 2 polymorphism associated with general intelligence in a healthy older population. Mol Psychiatry 2003, 8(1):14-18.

14. Papassotiropoulos A, Bagli M, Feder O, Jessen F, Maier W, Rao ML, Ludwig M, Schwab SG, Heun R: Genetic polymorphism of cathepsin D is strongly associated with the risk for developing sporadic Alzheimer's disease. Neurosci Lett 1999, 262(3):171-174.

15. Papassotiropoulos A, Bagli M, Kurz A, Kornhuber J, Forstl H, Maier W, Pauls J, Lautenschlager N, Heun R: A genetic variation of cathepsin D is a major risk factor for Alzheimer's disease. Ann Neurol 2000, 47(3):399-403.

16. Beyer K, Lao Jl, Latorre P, Ariza A: Age at onset: an essential variable for the definition of genetic risk factors for sporadic Alzheimer's disease. Ann N Y Acad Sci 2005, 1057:260-278.

17. Mariani E, Seripa D, Ingegni T, Nocentini G, Mangialasche F, Ercolani S, Cherubini A, Metastasio A, Pilotto A, Senin U, et al: Interaction of CTSD and A2M polymorphisms in the risk for Alzheimer's disease. J Neurol Sci 2006, 247(2):187-191.

18. Schuur M, Ikram MA, van Swieten JC, Isaacs A, Vergeer-Drop JM, Hofman A, Oostra BA, Breteler MM, van Duijn CM: Cathepsin D gene and the risk of Alzheimer's disease: a population-based study and meta-analysis. Neurobiol Aging 2011, 32(9):1607-1614.

19. Sun Y, Shi JJ, Zhang SZ, Tang MN, Han HY, Guo YB, Ma C, Liu XH, Li T: [The C224T polymorphism in the cathepsin D gene is not associated with sporadic Alzheimer's disease in Chinese]. Yi Chuan 2005, 27(2):190-194.

20. Li XQ, Chen D, Zhang ZX, Qu QM, Zhang JW: Association between cathepsin D polymorphism and Alzheimer's disease in a Chinese Han population. Dement Geriatr Cogn Disord 2004, 18(2):115-119.

21. Jhoo JH, Park WY, Kim KW, Lee KH, Lee DY, Youn JC, Choo IH, Seo JS, Woo $\mathrm{Jl}$ : Lack of association of cathepsin D genetic polymorphism with Alzheimer's disease in Koreans. Arch Gerontol Geriatr 2005, 41(2):121-127.

22. Matsui T, Morikawa Y, Tojo M, Okamura N, Maruyama M, Hirai H, Chiba H, Matsushita S, Higuchi S, Arai H, et al: Cathepsin D polymorphism not associated with Alzheimer's disease in Japanese. Ann Neurol 2001, 49(4):544-545.

23. Mcllroy SP, Dynan KB, McGleenon BM, Lawson JT, Passmore AP: Cathepsin D gene exon 2 polymorphism and sporadic Alzheimer's disease. Neurosci Lett 1999, 273(2):140-141.

24. Bhojak TJ, DeKosky ST, Ganguli M, Kamboh MI: Genetic polymorphisms in the cathespin $D$ and interleukin- 6 genes and the risk of Alzheimer's disease. Neurosci Lett 2000, 288(1):21-24.

25. Menzer G, Muller-Thomsen T, Meins W, Alberici A, Binetti G, Hock C, Nitsch RM, Stoppe G, Reiss J, Finckh U: Non-replication of association between cathepsin D genotype and late onset Alzheimer disease. Am J Med Genet 2001, 105(2):179-182.

26. Bertram L, Guenette S, Jones J, Keeney D, Mullin K, Crystal A, Basu S, Yhu S, Deng $A$, Rebeck GW, et al: No evidence for genetic association or linkage of the cathepsin D (CTSD) exon 2 polymorphism and Alzheimer disease. Ann Neurol 2001, 49(1):114-116.

27. Emahazion T, Feuk L, Jobs M, Sawyer SL, Fredman D, St Clair D, Prince JA, Brookes AJ: SNP association studies in Alzheimer's disease highlight problems for complex disease analysis. Trends Genet 2001, 17(7):407-413.

28. Bagnoli S, Nacmias B, Tedde A, Guarnieri BM, Cellini E, Ciantelli M, Petruzzi C, Bartoli A, Ortenzi L, Serio A, et al: Cathepsin D polymorphism in Italian sporadic and familial Alzheimer's disease. Neurosci Lett 2002, 328(3):273-276.

29. Mateo I, Sanchez-Guerra M, Combarros O, Llorca J, Infante J, Gonzalez-Garcia J, del Molino JP, Berciano J: Lack of association between cathepsin D genetic polymorphism and Alzheimer disease in a Spanish sample. Am J Med Genet 2002, 114(1):31-33.

30. Styczynska M, Religa D, Pfeffer A, Luczywek E, Wasiak B, Styczynski G, Peplonska B, Gabryelewicz T, Golebiowski M, Kobrys M, et al: Simultaneous analysis of five genetic risk factors in Polish patients with Alzheimer's disease. Neurosci Lett 2003, 344(2):99-102.

31. Ingegni T, Nocentini G, Mariani E, Spazzafumo L, Polidori MC, Cherubini A, Catani M, Cadini D, Senin U, Mecocci P: Cathepsin D polymorphism in Italian elderly subjects with sporadic late-onset Alzheimer's disease. Dement Geriatr Cogn Disord 2003, 16(3):151-155.

32. Blomqvist ME, Reynolds C, Katzov H, Feuk L, Andreasen N, Bogdanovic N, Blennow K, Brookes AJ, Prince JA: Towards compendia of negative genetic association studies: an example for Alzheimer disease. Hum Genet 2006, 119(1-2):29-37.

33. Davidson Y, Gibbons L, Pritchard A, Hardicre J, Wren J, Tian J, Shi J, Stopford C, Julien C, Thompson J, et al: Genetic associations between cathepsin D exon 2 C-> T polymorphism and Alzheimer's disease, and pathological correlations with genotype. J Neurol Neurosurg Psychiatry 2006, 77(4):515-517.

34. Capurso C, Solfrizzi V, D'Introno A, Colacicco AM, Capurso SA, Bifaro L, Menga R, Santamato A, Seripa D, Pilotto A, et al: Short arm of chromosome 11 and sporadic Alzheimer's disease: catalase and cathepsin D gene polymorphisms. Neurosci Lett 2008, 432(3):237-242.

35. Albayrak O, Tirniceriu A, Riemenschneider M, Kurz A, Scherag A Egensperger $R$ : The cathepsin D (224C/T) polymorphism confers an increased risk to develop Alzheimer's disease in men. $J$ Gerontol A Biol Sci Med Sci 2010, 65(3):219-224.

36. Crawford FC, Freeman MJ, Schinka J, Abdullah LI, Richards D, Sevush S, Duara R, Mullan MJ: The genetic association between Cathepsin D and Alzheimer's disease. Neurosci Lett 2000, 289(1):61-65.

37. Bertram L, McQueen MB, Mullin K, Blacker D, Tanzi RE: Systematic meta-analyses of Alzheimer disease genetic association studies: the AlzGene database. Nat Genet 2007, 39(1):17-23.

38. Ntais C, Polycarpou A, loannidis JP: Meta-analysis of the association of the cathepsin D Ala224Val gene polymorphism with the risk of Alzheimer's disease: a HuGE gene-disease association review. Am J Epidemiol 2004, 159(6):527-536.

39. Papassotiropoulos A, Lewis HD, Bagli M, Jessen F, Ptok U, Schulte A, Shearman MS, Heun R: Cerebrospinal fluid levels of beta-amyloid(42) in patients with Alzheimer's disease are related to the exon 2 polymorphism of the cathepsin D gene. Neuroreport 2002, 13(10):1291-1294.

40. Corder EH, Huang R, Cathcart HM, Lanham IS, Parker GR, Cheng D, Smith S, Poduslo SE: Membership in genetic groups predicts Alzheimer disease. Rejuvenation Res 2006, 9(1):89-93.

41. Papassotiropoulos A, Bagli M, Jessen F, Maier W, Forstl H, Kurz A, Heun R: Interaction of two genes possibly involved in the regulation of the 
amyloid precursor protein (APP) processing. Mol Psychiatry 2000, 5(3):240-241.

42. Kolsch H, Ptok U, Majores M, Schmitz S, Rao ML, Maier W, Heun R: Putative association of polymorphism in the mannose 6-phosphate receptor gene with major depression and Alzheimer's disease. Psychiatr Genet 2004, 14(2):97-100.

43. Capurso C, Solfrizzi V, D'Introno A, Colacicco AM, Capurso SA, Mastroianni F, Liaci M, Vendemiale G, Capurso A, Panza F: The cathepsin D gene exon 2 (C224T) polymorphism and sporadic Alzheimer's disease in European populations. J Gerontol A Biol Sci Med Sci 2005, 60(8):991-996.

44. Prince JA, Feuk L, Sawyer SL, Gottfries J, Ricksten A, Nagga K, Bogdanovic N, Blennow K, Brookes AJ: Lack of replication of association findings in complex disease: an analysis of 15 polymorphisms in prior candidate genes for sporadic Alzheimer's disease. Eur J Hum Genet 2001, 9(6):437-444.

45. Bernstein $\mathrm{HG}$, Bruszis $\mathrm{S}$, Schmidt D, Wiederanders B, Dorn A Immunodetection of cathepsin $D$ in neuritic plaques found in brains of patients with dementia of Alzheimer type. J Hirnforsch 1989, 30(5):613-618.

46. Cataldo AM, Barnett JL, Berman SA, Li J, Quarless S, Bursztajn S, Lippa C, Nixon RA: Gene expression and cellular content of cathepsin D in Alzheimer's disease brain: evidence for early up-regulation of the endosomal-lysosomal system. Neuron 1995, 14(3):671-680.

doi:10.1186/1471-2377-14-13

Cite this article as: Mo et al: Lack of association between cathepsin D C224T polymorphism and Alzheimer's disease risk: an update metaanalysis. BMC Neurology 2014 14:13.

\section{Submit your next manuscript to BioMed Central and take full advantage of:}

- Convenient online submission

- Thorough peer review

- No space constraints or color figure charges

- Immediate publication on acceptance

- Inclusion in PubMed, CAS, Scopus and Google Scholar

- Research which is freely available for redistribution 